\title{
Reform of the Mode Training Professional Secretarial Talents
}

\author{
Liu Yuehua
}

(Nanchang Institute of Science and Technology, Nanchang 330108)

Keywords: Secretary science; Innovation ability; Talent training mode; Teaching reform

\begin{abstract}
With the great emphasis on the development of "innovation" in contemporary society, it is particularly urgent and important for colleges and universities to continuously promote the reform and exploration of the creative ability of secretarial professionals as the base and cradle for training secretarial professionals. The main connotation of the creative ability of secretarial scholars includes healthy personality and independent personality, strong innovative consciousness and multi-dimensional innovative thinking, dare to break the traditional thinking and stereotypes. This paper explores the path of the reform and exploration of the innovation ability of college secretarial professionals. Starting from the innovative secretary training professional talent training mode, paying attention to the cultivation of students' innovative ability; reforming and innovating the teaching evaluation system and examination system; attaching importance to the cultivation and improvement of teachers' innovative ability.
\end{abstract}

\section{Introduction}

At present, the reform direction of the secretarial professional training mode should be the application of the secretarial talent training model. Combine academic education with professional quality education, keep pace with social needs, and adhere to career-oriented talent development ideas. It more vividly reflects its characteristics of industry, application, innovation and complexness, and cultivates secretarial talents with application innovation capabilities. On the basis of previous studies, this paper first defines the concept and the scope of the research. Secondly, through the SWOT research method, a comprehensive analysis of the training of secretarial professionals is conducted. Further demonstrate the ability of talents in today's workplace, especially high-quality compound secretarial talents, to infer the knowledge and ability system that should be possessed by secretarial professionals.

\section{Problems in Professional Secretarial Education}

\section{The tendency to marginalization is more prominent}

The so-called marginalization means that some colleges and universities do not pay enough attention to the professional education of secretarial studies, and they are placed on the margins. They cannot give the same support as other professions. Even for some schools that have a long history and a good accumulation of the profession, some leaders often say that they want to "remove" the secretarial program. They often emphasize the so-called professional counterpart rate and employment rate or crowd out the secretarial major in order to highlight the so-called school-running characteristics. Especially at some engineering schools, this problem is more prominent. Even if some schools retain the secretarial science, this major is placed behind other professions with insufficient investment in professional construction. In addition, due to historical and practical reasons, public opinion has always been biased against the secretarial profession. Coupled with the "secretary corruption" problem exposed in recent years, it also directly or indirectly affects the reputation of the secretarial profession and secretarial science, which leads to the worrying development of secretarial professional education.

\section{Heterogeneity is much serious}

The so-called heterogeneity refers to the development of secretarial professional education. Due to the influence of certain internal and external factors, the professional deviates from its own track in the development of connotation and deviates from the attributes of the secretarial profession. For 
example, many colleges and universities have blindly launched the teaching project, and started the fast-tracking secretarial profession, making the quick-recording technology become the core skill of the leading profession, making the comprehensive secretarial professional teaching become a single quick-recording technical training. Undoubtedly, we should fully affirm the positive effect of the quick-recording technology on expanding the scope of the secretarial science and enhancing the employability of students.

\section{The problem of narrow vision still exists}

The so-called narrow vision means that the professional education of secretarial studies has not developed in parallel with the professional practice of secretaries, and professional education is still in the traditional vision. Today's secretarial professional activities have long surpassed the connotation of secretarial work in the traditional sense and are shifting from a "housekeeping" secretary to a "managed" secretary. Secretarial professional education must examine itself with a new perspective, comprehensively deepen reform, and constantly develop and innovate; it cannot stay in the traditional mindset and cognitive vision, follow the old professional positioning, training objectives, curriculum, textbook writing, teaching methods, assessment methods, etc., resulting in professional education lack of the times, behind the reality.

\section{Main Connotation of Undergraduate Talent Innovation Ability in Secretarial Science}

Innovative ability refers to the potential psychological quality that people display in the process of successfully completing the activities of creating new things based on the original knowledge and experience. The ability to innovate is characterized by comprehensiveness, originality, inquiry and structural optimization. Specific to the secretarial work, "the ability of the secretarial staff to innovate is that the secretary flexibly and creatively uses the known knowledge and information to present unique insights, solve or complete the work assigned by the organization and leadership in a novel way according to the identified goals and needs".

The creative ability of the professional secretary means that the secretary dares to break through the traditional thinking ability on the basis of familiarity with the company, boldly break through the rules and regulations, and propose creative ideas. According to the definition of innovation ability and secretarial innovation ability of scholars, we can summarize the main connotations of the undergraduate talent innovation ability of secretarial science into the following three aspects.

\section{Healthy personality and independent personality}

A healthy personality and independent personality are the sum of the more stable psychological and behavioral characteristics of the individual. With the deepening of reform and opening up and the development of market economy, Chinese society is in a transitional period of new and old transitions, and people's ways of thinking, values, lifestyles, and behavioral patterns have undergone tremendous changes. The formation of healthy personality and independent personality is an important part of talent cultivation. Without a healthy personality and independent personality, not only can we not correctly face and solve problems, let alone break through innovation.

\section{Strong sense of innovation and multidimensional innovative thinking}

Innovative consciousness refers to a psychological tendency to discover problems and actively explore, that is, interest, motivation, initiative and enthusiasm of thinking activities. It is necessary to cultivate undergraduate students of secretarial majors to be proactive in understanding, thinking, and thinking, constantly pursuing innovation, forming an intuitive and active attitude, and consistently pursuing excellence. And it is necessary to pay attention to the cultivation of students' ideal desires, value pursuits, hobbies, desires for knowledge, curiosity and other factors that form innovative consciousness and stimulate students' creative potential in secretarial work.

\section{Dare to break the traditional mindset and stereotypes}

Bonding innovation means critique and negation of tradition. Traditional linear thinking, one-way thinking, forward thinking, convergent thinking, book-only thinking and supreme thinking can no longer meet the needs of the current complex and changing secretarial work. Therefore, we must pay attention to cultivating students to break the shackles of traditional thinking, using innovative thinking, forward thinking, broadening ideas, constantly exploring new ideas and new 
methods, proposing new suggestions and new countermeasures, and promoting innovation in secretarial work.

\section{Ways to Reform the Mode of Training Secretarial Talents at Colleges}

The secretarial science major is an applied discipline. It has a close relationship with the market economy and can directly test the quality of secretarial education through social practice activities. In order to train high-quality and high-skilled professional secretarial talents, it is necessary to reform the training mode.

\section{Clarify training mode}

The training goal of the secretarial major in China is to train professionals with both Marxist theoretical cultivation and higher policy level, and to be competent in both the party and government leading organs at or above the county level and the key business operations of the secretarial institutions of middle and above enterprises and institutions. The secretarial major should be the cultivation of middle and senior secretarial talents, and the difference in the level of training objectives. Each school can locate the professional training direction of secretarial studies according to the characteristics of its own institutions and the market needs of its region, embodying the characteristics and differences, and presenting diversified characteristics, such as: the direction of the political secretary, the direction of the business secretary, the direction of the foreign secretary, the direction of the judicial secretary, and so on. According to the direction of the cultivation, various types of training objectives are set up, and specialized individualized training programs are arranged to meet the different needs of administrative agencies, institutions, and large and medium-sized enterprises for various secretarial talents.

\section{Optimize course structure}

The rational construction of the curriculum system should be based on the analysis of talent demand, based on the training objectives, combined with the "National Professional Standards" and the actual situation of the development of the university itself. Therefore, the cultivation of secretarial professional competence should be based on the professional background of the party and government organs, the secretaries of enterprises and institutions, and related posts. Taking the theories of secretarial studies, Chinese language and literature and management as the basis of the discipline, the goal is to cultivate students' management coordination ability, staff assistant ability, information processing ability and communication adaptability.

\section{Focus on practical ability}

The practical curriculum system for secretarial undergraduate majors should be based on social needs, make full use of the teaching resources inside and outside the educational institutions, and correctly handle the relationship between theoretical teaching, practical teaching and graduation internship. Put the practical teaching objectives into the teaching links step by step, so that students can master the systematic professional skills in the process of practicing teaching. It is necessary to integrate a secretarial professional course to highlight the practicality of the course and the differences in different directions.

\section{Conclusion}

The entry of secretary into the teaching catalogue is both an opportunity and a challenge for the development of the secretarial discipline. Faced with the dilemma of professional education and talent training for college secretaries, we must have the courage to face the problems. The development of secretarial professional education is determined by the law of the secretarial profession. Thought is the precursor of action. Only by following the objective laws of professional education and personnel training, accurately positioning the secretarial training objectives, rationally constructing a professional curriculum system, and perfecting the construction of the teaching staff, the secretarial science can develop and grow. 


\section{References}

[1]Golden D D, Secretary O D, Agrawal D D, et al. ,014 Building Bridges to Success: An Update on the Action Plan to Transition Adult Basic Education Students Into Postsecondary Education and Training[J]. Biotechnology \& Bioengineering, 2013, 110(7):1895-1902.

[2]Ke L I. Exploration and Thinking of Higher Vocational Secretary Major of Human Resource Management Course Teaching Reform[J]. Guide of Science \& Education, 2013.

[3]Xiao Y. Research on the Teaching Mode of Practice Training for Vocational Secretary Major Based on School- enterprise Cooperation[J]. Journal of Hubei Correspondence University, 2016.

[4]Long X H. The Research of Secretary Major Curriculum Construction Based on Professional Behavior-oriented.—-Take the "Secretarial Writing Practice" as an Example[J]. Education Teaching Forum, 2017.

[5]Huang J, Department C. Curriculum reform of secretary major based on the cultivation of vocational core competence[J]. Journal of Harbin Vocational \& Technical College, 2014.

[6]Tian L. Introduction to Secretary Major and Construction Planning[C]// International Conference on Education, Management and Computing Technology. 2015.

[7]Li Z, Wang X. Some Thoughts on Laboratory Technicians' Participation in Practical Training Teaching of Secretary Major in Higher Vocational Education[J]. Science Education Article Collects, 2017.

[8]Li F. The Exploration and Analysis of the Curriculum Reform of Public Computer Course in Secretary Major of Higher Vocational Colleges Based on the Structure of Applied Knowledge[J]. Journal of Beijing Institute of Graphic Communication, 2017.

[9]Xiong Q, Polytechnic T. On Status Quo of Higher Vocational Secretary Major Students' Certificate Tests and Countermeasures[J]. Guide of Science \& Education, 2014.

[10]Wang Y. Practice and Exploration on Promoting Social Service Ability of Secretary Major in Vocational Colleges[J]. Journal of Wenzhou Vocational \& Technical College, 2015.

[11]Liu D. The analysis of computer based modular teaching in higher vocational secretary major-Take Jinzhou Normal College as an example[J]. Journal of Liaoning Teachers College, 2015.

[12]Cai L Y. The Investigation and Thinking of Impelling Grassroots Management Modernization by Major Residency Secretary in Liangshan Yi District[J]. Journal of Xichang College, 2017. 